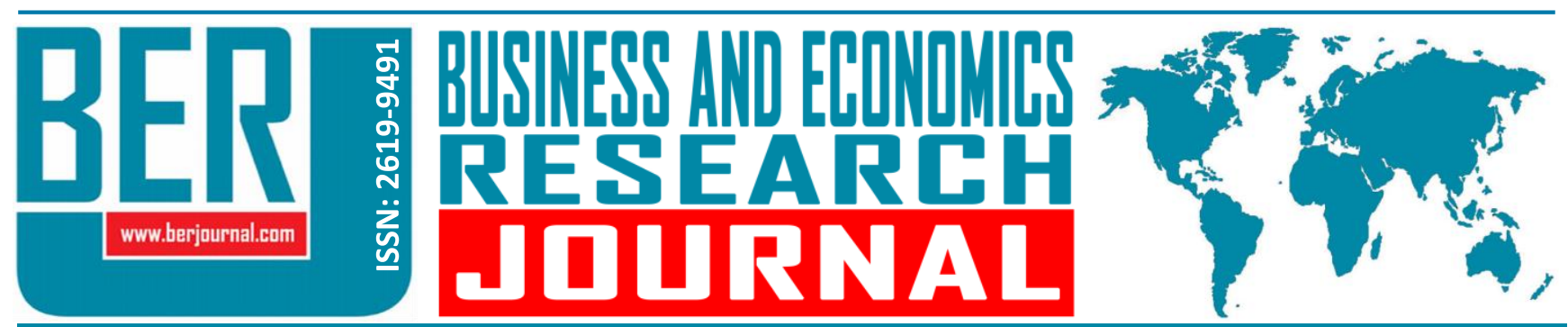

Business and Economics Research Journal Vol. 10, No. 2, 2019, pp. 451-468 doi: 10.20409/berj.2019.179

\section{Entelektüel Sermaye Unsurları Arasındaki İlişki ve Bu Unsurların Yönetilmesi: B-fit İşletmeleri Örneği*}

\section{Yeter Aytul Dagli Ekmekci ${ }^{a}$}

Öz: Günümüz bilgi çağı ekonomisinde hemen hemen tüm sektörlerde finansal tablolarda görünmeyen ancak değer yaratmada ön plana çıkan entelektüel sermaye kavramı önem kazanmıştır. Son yıllarda ülke ekonomilerinde oldukça büyük öneme sahip, kitleleri peşinden sürükleyen ve alt alanlarıly her geçen gün çeşitlenerek büyüyen bir sektör olan sporda da entelektüel sermayenin önemi göz önünde bulundurulmalıdır. Ancak Türkçe alan yazında spor işletmelerinde entelektüel sermaye yönetimiyle ilgili oldukça az çalışma bulunmaktadır. Bu nedenle bu çalışma Türkçe alan yazınında özellikle entelektüel sermaye unsurları arasındaki ilişkiye yönelen ilk çalışma niteliğini taşımaktadır. Çalışmanın amacı işletmelerde piyasa değerini artıran maddi olmayan varlıkların önemine vurgu yaparak, entelektüel sermayenin unsurları olarak belirtilen yapısal sermaye, müşteri sermayesi ve insan sermayesine ve bu unsurlar arasındaki ilişkiye spor hizmeti sunan işletmelerde nasıl bakıldığının ortaya konulmasıdır. Ülkemizde birçok bölgede toplamda 50 farklı ilde 200'e yakın işletmeyle faaliyet gösteren B-fit işletmeleri ele alınmıştır. Aynı zamanda işletme yöneticilerinin bilgi paylaşımı konusundaki fikirleri de değerlendirilmiştir. Veriler anket tekniği ve doküman analizi ile toplanmış, istatistiki veri analizi yöntemi ile analiz edilmiştir. Analizler sonucunda entelektüel sermaye faktörleri arasında araştırmanın varsayımlarına da uygun olarak orta derecede anlamlı ilişki olduğu görülmüştür.

\section{The Relationship between Intellectual Capital Elements and Management of these Elements: Example of B-fit Businesses}

Abstract: In today's knowledge economy, the intellectual capital, which doesn't appear in the financial statements, but comes to the forefront in creating value, has gained importance. The prospect of intellectual capital should be taken into account in sport sector, which has a very large prevalence in the country's economies. However, there are few studies on intellectual capital management in the field of sports at Turkish literature and this study is a preliminary work especially oriented towards the relationship between intellectual capital elements. The aim of the study is to emphasize the importance of intangible assets which increase the market value and to reveal how the managers of sport service businesses are evaluating the elements structural capital, consumer capital and human capital. B-fit enterprises with 200 businesses in 50 different cities are considered. It is also evaluated the ideas of business managers about information sharing. The data were collected by survey and document analyzing method and analyzed with statistical data analysis method. As a result, it was seen that there was a moderately significant relationship between the intellectual capital factors.
Anahtar Sözcükler: Entelektüel Sermaye, Bilg Yönetimi, Piyasa Değeri, Spor İşletmeleri, Spor Finansmanı

JEL: M12, O34, Z20

$\begin{array}{ll}\text { Geliş } & : 19 \text { Kasım } 2018 \\ \text { Düzeltme } & : 16 \text { Ocak } 2019 \\ \text { Kabul } & : 25 \text { Ocak } 2019 \\ \text { Tür } & : \text { Araştırma }\end{array}$

Keywords: Intellectual Capital, Knowledge Management, Market Value, Sports Businesses, Sports Financing

JEL: M12, O34, Z20

Received : 19 November 2018

Revised : 16 January 2019

Accepted : 25 January 2019

Type : Research 


\section{Giriş}

Küreselleşme ve buna bağlı olarak rekabetin yoğun olarak hissedildiği günümüz ekonomisinde işletmelerin başarıları ve diğer işletmelere karşı rekabet güçlerini arttırabilmeleri, sahip oldukları entelektüel sermaye varlıklarına ve bunları değer yaratacak şekilde yönetebilmelerine bağlıdır. Entelektüel sermaye; günümüz çağdaş işletmecilik anlayışında en önemli yapıtaşı olan bilgiyle beraber değerli bir sermaye unsurudur.

Geleneksel endüstri çağında bir işletmenin duran varlıkları olarak bina, makine, tesis ve teçhizat ekonomik güç kaynağı iken günümüz bilgi çağında yetkinlikler, süreçler ve insanlar gibi fikri mülkler, mevcut ve gelecekteki zenginliğin gizli güç kaynağı haline gelmiştir (Guthrie, Cuganesan ve Ward. 2007: 3).

Abeysekera ve Guthrie (2004) entelektüel sermayenin ortaya çıkmasında küreselleşme, yükselen teknolojiler, değişen müşteri talepleriyle siyasi ve ekonomik yapı değişikliklerini içeren mevcut işi yeniden şekillendiren kuvvetlerin etkili olduğunu belirtmektedir. Özellikle gelişmekte olan ülkelerdeki işletmelerin sürdürülebilir büyüme sağlayabilmesi ve gelişmiş ülkelerdeki işletmelerle rekabet edebilmesi için entelektüel sermayenin ölçülmesinin gerekli olduğunu belirtmektedir.

Bilgi yönetimi, işletmenin elindeki ham bilginin ve verilerin insan sermayesi ve ilişkisel sermaye haline dönüştürülmesi faaliyetlerini kapsamaktadır. Bu tanımdan anlaşılacağı üzere entelektüel sermaye yönetimi bilgi yönetiminden daha geniş kapsamlıdır (Edvinsson1997: 366-372). Edvinsson; entelektüel sermayeyi değere dönüşebilen bilgi olarak tanımlamıştır. İşletmelerin bilgiyi toplaması, işleyerek yorumlaması sonucunda ekonomik bir değere dönüştürmesi entelektüel sermaye kavramına olan önemi ve ilgiyi arttırmıştır (Alagöz, 2007: 168). Entelektüel sermaye alanı, maddi olmayan değer varlıklarının sistematik olarak kodlanmasıyla, niceliksel olarak ifade edilmesi ve bu sayede maddi olmayan varlıkların da muhasebe kayıtlarında değerlendirilmesinin örgütsel olarak gerekliliğinin fark edilmesiyle doğmuştur. Bu nedenle işletmelerde entelektüel sermayenin etkili yönetimi gerekli görülmektedir(Andrikopoulos ve Kaimenakis, 2006: 3).

Entelektüel sermaye; bir işletmenin sahip olduğu bilgiyle alakalı, elle tutulamaz değerlerini ifade etmektedir (Chang, 2008: 299). Çetin'e göre de entelektüel sermaye kâra dönüştürülebilen bilgidir (Çetin, 2005: 359). Geleneksel muhasebe analizlerine göre yapılan finansal tablolardaki bilgilerle yapılan finansal performans ölçümleri; şirket kârlılı̆ı, verimlilik, borçları geri ödeme yeterliliği, likidite gibi değerleri ölçmektedir. Ancak maddi olmayan unsurların ve işletme değerlerinin ölçümü finansal performans ölçümleriyle yapılamamaktadır. Bu nedenle finansal performans ölçümü değer odaklı stratejik kararların alınmasında etkin bir yol değildir. Bunun yerine bilgi varlıkları olarak bahsedilen entelektüel varlıların ölçümünü kapsayan ve finansal olmayan ölçüm modelleri kullanılmaktadır (Aslanoğlu, 2006: 153).

Bir işletmenin gelecekte de varlığını devam ettirebilmesinin entelektüel sermaye unsurları olan; beşeri (insan ve yeterlilikler) sermayenin, yapısal (rutinler ve iç ilişkiler) sermayenin ve müşteri (dış ilişkiler ve markalar) sermayesinin etkin yönetimiyle mümkün olacağı yapılan çalışmalarda ortaya konmuştur. Geçmiş ve geleceğin oluşturduğu değerin değerlendirilebilmesi; entelektüel sermayenin ölçülmesi ve sonuçlarının raporlanmasıyla mümkün olacaktır (Hobikoğlu, 2011: 87). Her üç entelektüel sermaye bileşeninin verimli yönetimi örgütsel refahın ve servetin bir faktörü olarak görülmelidir (Mladkova, 2013: 294. Entelektüel sermayenin ülkemizde ve dünyadaki işletmeler açısından önemine yapılan vurgu spor sektörünü de içine alacak şekilde her geçen gün artmaktadır. Ancak son yıllarda entelektüel sermaye ve bu sermayenin ölçülmesi üzerine farklı sektörlerde çalışmalar yapılmasına karşın, spor sektöründe çok fazla çalışma bulunmamaktadır.

Küreselleşen dünyada her geçen gün büyüyen spor endüstrisinde spor işletmelerinin de profesyonel iş modelleriyle yönetilmesinin gerekliliği kabul görmektedir (Sönmezoğlu ve Çoknaz, 2014: 2). Artık bu işletmeler diğer sektörlerdeki işletmelerle yenilik, maliyet liderliği, insan kaynakları yönetimi, piyasa değerleri gibi performans ve başarı göstergeleri açısından da rekabet edebilir düzeydedirler. Belirtilen bu durumlara ek olarak gelişen ve farklılaşan spor endüstrisinin diğer özelliklerini de göz önünde bulundurarak, spor işletmelerinde entelektüel sermaye unsurlarının dikkate alınmasının gerekliliği ve çalışmanın ana varsayımı 
olan entelektüel sermaye unsurları arasında ilişkinin varlığının değerlendirilmesi bu çalışmanın ortaya çıkmasındaki temel nedenini oluşturmaktadır.

Bu çalışmada Türkiye genelinde 50 ilde 200 merkezi olan ve sadece kadınlara sportif hizmet veren Bfit spor merkezleri ele alınmıştır. Daha önce Ölçer ve Şanal (2007) tarafından Türkiye'deki büyük sanayi işletmelerine uygulanan ve entelektüel sermayenin boyutları olan insan sermayesi, yapısal sermaye ve ilişkisel sermayeyi ölçmek için kullanılan 47 maddelik anket soruları sektörel özellikler dikkate alınarak uyumlaştırılmış ve spor işletmelerine uygulanmıştır. Çalışmanın ilk bölümünde entelektüel sermaye (IC) ve entelektüel sermaye unsurları kısaca açıklanmıştır. Daha sonraki bölümde bugüne kadar yapılan çalışmalar ve farklı sektörlerdeki uygulamalar aktarılmıştır. Üçüncü bölümde ise spor sektöründe entelektüel sermayenin ölçülmesi ve önemi açıklandıktan sonra araştırmanın yöntem ve verileri hakkında bilgi verilmiştir. Sonuçlar son bölümde ele alındıktan sonra çalışma öneriler ve yorumlarla sonlandırılmıştır.

\section{Entelektüel Sermaye Tanımı ve Unsurları}

\subsection{Tanım}

Alan yazında birçok entelektüel sermaye tanımına rastlanmaktadır. Bu tanımlarda kavram farklı araştırmacılar ve kurumlara göre farklı bakış açılarıyla yorumlanmıştır. Genel bir tanımlama yapmadan önce "entelektüel" ve "sermaye" kelimelerini tek tek ele alacak olursak, "entelektüel" zihinsel veya düşünsel etkinliğe yönelmiş, eleştirisel becerisi yüksek, bilgili, topluma faydalı ve öncü olan, aydın ve çağdaş kimsedir (https://www.turkcebilgi.com/entelektuel). Bir başka tanımıyla, kaynağı batı dillerine dayanan, sanat kültür ve bilim alanlarında yüksek derecede eğitim görmüş kimse ya da toplumun aydın kesimini ifade eden bir kavramdır (Seyidoğlu, 1999: 162).

"Sermaye" ise, genel olarak, servetin daimi ve sabit olarak kabul edilen kısmıdır (https://www.turkcebilgi.com/sermaye). Diğer bir tanımıyla, bir işletme için gerekli olan tesislerin ve binaların yapımında, makine ve donanım için gerekli olan üretim faaliyetlerinde kullanılan tüm araç ve gereçleri kapsar. İşletme alanında ise sermayenin tanımı işletmenin tüm mal varlığını, piyasadaki imajını, piyasa değerini ve marka bilinirliğini kapsar (Seyidoğlu, 1999: 526).

Entelektüel sermaye kavramı ilk kez 1960 'lı yıllarda kullanılmaya başlanmıştır. Gündemde var olan diğer örgütsel konuların arasında uzun yıllar pek dikkat çekmemiştir. Ancak 1990'lı yılların sonlarına doğru uygulama alanında gündeme gelmiş ve yaygın biçimde tartışılır hale gelmiştir (Kanıbir, 2004: 78).

Stewart'ın entelektüel sermaye tanımı, "işletmeye piyasada rekabet üstünlüğü sağlayan, işletme çalışanlarının bildiği her şeyin toplamıdır" şeklindedir. Brooking ise entelektüel sermayeyi, "işletmelerin faaliyetlerini sürdürebilmesi için sağlanan maddi olmayan varlıkların tümü" olarak tanımlamıştır. illk profesyonel entelektüel sermaye yöneticisi olarak bilinen Edvinsson ve Skaikhise entelektüel sermayeyi "değere dönüştürülebilen bilgi" olarak tanımlamışlardır (Akt: Ölçer ve Şanal, 2007: 480). Buna göre entelektüel sermaye bilgi, entelektüel mülkiyet ve görünmeyen kaynaklardan oluşmaktadır (Yorulmaz ve Alkan, 2018: 623).

Entelektüel sermaye, işletmeye değer kazandırmak amacı ile ele alınabilecek her türlü yönetim yetenekleri, patentler, iş süreçleri, kişisel tecrübe, müşteri ve tedarikçileriyle ilgili bilgilerin tamamını içermektedir (Yorulmaz ve Alkan, 2018: 623). Bu tanımlamalardan yola çıkılarak entelektüel sermaye genel olarak; işletmelerin maddi olmayan varlıklarının verimli ve etkin bir şekilde yönetilmesi, ölçülmesi ve raporlanması olarak belirtilebilir.

\subsection{Entelektüel Sermayenin Unsurları}

Entelektüel sermayenin unsurları da tanımında olduğu gibi farklı araştırmacılar tarafından farklı boyutlarda ele alınmıştır. Tüm işletmelerin entelektüel sermaye unsurları açsından birbirlerine karşı farklı rekabet üstünlüğü sağlayan avantajlı yönleri vardır. Şüphesiz stratejik yönetim kavramının incelenmeye başlandığı yıllardan bu yana entelektüel sermaye unsurları, üzerinde en fazla çalışılan konu olmuştur. Konuya bu alandaki çalışmalarıyla büyük katkı sağlayan isimler; Porter, Glueck ve Chandler gibi araştırmacılardır. 
Porter, Glueck ve Chandler, rekabet üstünlüğünü oluşturan insan faktörüne ait tüm değer ve imkânların ortaya çıkarılması, öneminin ölçülmesi, oluşturduğu etkinin boyutunun değerlendirilmesi gibi konular üzerinde durmuşlardır (Arıkboğa, 2003: 75).

Şekil-1'de entelektüel sermayenin unsurları, alan yazındaki genel olarak kabul görmüş haliyle yapısal sermaye, müşteri sermayesi ve insan sermayesi adı altında toplanmıştır.

Şekil 1. Entelektüel Sermaye Unsurları Raporlaması

\begin{tabular}{|l|l|l|}
\hline \multicolumn{3}{|c|}{ Entelektüel Sermaye Raporlama (ICR) Unsurları } \\
\hline A-Yapısal (İç) Sermaye & B-Müşteri (Dış) Sermayesi & C-İnsan Sermayesi \\
\hline Fikri mülkiyet & Markalar & Çalışanlar \\
Yönetim felsefesi & Müşteriler & Eğitim \\
Örgüt kültürü & Müşteri memnuniyeti & Öğrenimler \\
Yönetim süreçleri & Örgüt (işletme) ismi & İş ve teknik bilgiler \\
Bilgi sistemleri & Dağıtım kanalları & Girişimci ruh \\
Mali ilişkiler & İş ortaklıkları & \\
& Lisans anlaşmaları & \\
\hline
\end{tabular}

Kaynak: Guthrie vd., 2007: 6.

Oluşturulmuş bir amacın ve belirli bir bakış açısının olmadığı koşullarda entelektüel sermayenin varlık kazanması olası değildir. Entelektüel varlıkların tanımlanması ve yönetilebilmesi için işletmelerin bilgileri iyi analiz edip onlarla ne yapacağını, nerede nasıl kullanacağını bilmesi gerekir. Bunun için işletme, çalışanlarına bu ortam ve koşulları sağlamalıdır (Arıkboğa, 2003: 75). Benzer şekilde entelektüel sermaye unsurlarını oluşturan değerler ve yapıların da işletmeler tarafından tanımlanmış olması gerekir.

\subsubsection{Insan Sermayesi}

Bir işletmede çalışanların kendilerine verilen görev ve vazifeleri yerine getirebilmeleri için, kendilerinde var olan ve kullandıkları bilgi, beceri, deneyim, tecrübe, yaratıcılık ve yetenek özelliklerinin bir arada toplanması insan sermayesini oluşturur. Bu sermaye türü işletmelerin sahip olduğu değerleri, işletme felsefesini ve performansını içine alsa da işletmeler tarafından doğrudan sahiplenemez. Çünkü bu sermaye işletme çalışanlarına aittir (Bontis, 2001: 44). Bu durumda insan sermayesi çalışanın, işletmede çalışmaya devam ettiği sürece işletmenin sahip olduğu entelektüel sermayedir (Yorulmaz ve Alkan, 2018: 633).

İnsan sermayesinin oluşabilmesi için Gutrie'nin (2004) de bahsettiği gibi öncelikle çalışan insana ihtiyaç vardır ve bu çalışanların girişimci ruhta olmaları gerekmektedir. Şüphesiz ki işletmeler için en önemli unsur insan unsurudur. İşletmelerin faaliyetlerini sürdürebilmeleri, piyasada var olup rekabet ve üstünlük sağlayabilmeleri için alanında uzman, eğitimli, kendini geliştiren ve yenilikçi insan gücüne ihtiyaçları vardır. İşletmeler insan sermayesini güçlendirebilmek için çalışanlarına aidiyet duygusunu aşılamalıdır.

Bu durumda işletmelerin bünyesinde var olan, onları rakiplerinden ayıran ve en önemlisi de rakiplerince taklit edilemeyen önemli kaynaklarından biri olan insan sermayesine sürekli yatırım yapmak işletmeler için büyük bir gerekliliktir. Insan sermayesine yapılan yatırımlarla çalışanların bilgi birikimi, yaratıcılığı ve problem çözme yeteneği gelişecektir (Yorulmaz ve Alkan, 2018: 633). Bu sayede de işletmelerin rekabet gücü artacaktır.

\subsubsection{Yapisal Sermaye}

Yapısal sermaye işletme çalışanlarının verimliliğini destekleyen donanım, yazılım veri tabanları, patentler, markalar ve organizasyon yapıları gibi kavramlardan oluşur. Başka bir deyişle işletme çalışanlarının, eve gittiğinde işletmede bıraktığı her şeydir. Yapısal sermaye aynı zamanda, müşterilerle kurulan ilişkilerde meydana gelen müşteri sermayesini de beraberinde getirir. Yapısal sermaye insan sermayesinin tam aksine, işletme tarafından benimsenir ve işletmenin ticari çerçevesinde kullanılabilir (Bontis, 2001: 44). 
İşletmeler için insan sermayesinden sonra en önemli unsur yapısal sermayedir. İnsan sermayesinin oluşumuyla yapısal sermayenin de temelleri atılmış olur. Nitekim yapısal sermaye insan sermayesini destekleyici bir altyapıdır. İşletmenin sağladığı örgüt kültürü ve yönetim felsefesi içerisinde çalışanların birbiriyle kolay iletişimi ve geri dönüşümü destekleyen yapısal sermayenin, müşteriyle olan ilişki ve iletişimde de etkin ve destekleyici bir rolü vardır.

\subsubsection{Müşteri Sermayesi (iliş̧ki Sermayesi)}

Entelektüel sermayenin en önemli unsurlarından olan ilişki sermayesi, işletme zincirinin içinde yer alan tüm unsurlarla olan ilişkileri kapsamaktadır. Pazar ve müşteriler, ilişki sermayesinin en önemli unsurlarıdır. iliş̧ki sermayesi içinde tanımlanması gereken diğer önemli unsur ise hisse sahipleri, tedarikçiler ve toplumdur (Bozbura ve Toraman, 2004: 55).

İsletmeler piyasadaki varlıklarını sürdürmeyi ve verimliliklerini, bu sayede de kârlılıklarını artırmayı temel amaç edinmişlerdir. Bunun için müşterilere ve dolayısıyla müşteri memnuniyetine ihtiyaçları vardır. Müşteri memnuniyeti sağlandığında müşterinin işletmeye olan bağılığı devamlı olur ve bu sayede üretilen mal ve hizmetlere talep daima artar. Müşterilerle olan ilişkilerin geliştirilmesi işletmeye finansal anlamda büyük katkı sağlar. Bu sayede de entelektüel sermaye değeri artmış olur.

\section{Literatür Taraması}

Gelişen dünyada entelektüel sermayenin tüm sektörlerde olduğu gibi spor sektöründeki önemi de her gün artmaktadır. Ancak; yapılan alan yazın taramasında spor işletmelerinde entelektüel sermaye yönetimiyle ilgili oldukça az çalışmaya rastlanmıştır.

Farklı sektörlerdeki çalışmaların kapsam ve sonuçları genel olarak şu şekildedir.

Sanayi sektöründeki işletmeler üzerinde yapılan bir çalışmada Türkiye'deki büyük ölçekli sanayi işletmelerinin entelektüel sermaye uygulamaları incelenmiştir. Ölçer ve Şanal'ın (2007) inceledikleri ölçüm yöntemlerinin verileri, yöneticilerin işletmeleri için entelektüel sermaye yönetimine gerekli önemi verdiklerini ve entelektüel sermaye bileşenlerini geliştirmek için çaba harcadıklarını göstermektedir.

Bankacılık sektöründe ise ilk olarak Alagöz ve Özpeynirci (2007), entelektüel sermaye kavramının unsurları, muhasebeleştirilmesi ve raporlanması konuları üzerinde durmuş ve geleneksel muhasebe sisteminin maddi olmayan varlıklar hakkındaki bilgilerin açıklanmasına daha fazla önem vermesi gerektiği sonucuna ulaşmıştır. Kayalı, Yereli ve Ada (2007)'nın teknoloji sektöründeki işletmelerde entelektüel sermayenin işletme değeri üzerindeki etkisinin belirlenmesine yönelik olarak yapılan çalışmasında entelektüel katma değer katsayısı yöntemi uyguladığında işletmelerin maddi olmayan kaynak unsurlarına gereken düzeyde önem vermedikleri ve faaliyetlerini daha çok fiziksel varlıklarına dayandırdıkları ortaya çıkmıştır. Nuzumlalı (2008)'nın çalışmasında ise entelektüel sermayenin muhasebe bakış açısıyla değerlendirilmesi üzerinde durulmuştur. Çalışkan (2015) ise, Türkiye'de bankacılık sektöründe faaliyet gösteren işletmelerin entelektüel sermayelerinin işletme değeri üzerindeki etkisini inceleyerek bankaların verimliliği ve piyasa değerlemesinde insan sermayesinin etkilerinin olduğu, kârlılığında ise insan sermayesi etkisinden önce kullanılan sermayenin etkisinin olduğu sonucuna varılmıştır.

Türkiye'deki süt endüstrisi kuruşlarından birini ele alan Vatansever (2009) çalışmasında, entelektüel sermaye kavramı ve bilgi altyapısının entelektüel sermayenin gelişimi üzerine etkisini araştırmış ve sonuç olarak ele alınan süt işletmesinin entelektüel sermaye unsurlarını etkin bir şekilde kullandığı ve bunun da örgüt kültürü yapısına olumlu yansıdığı tespit edilmiştir. Muş (2010) çalışmasında, bilgi yoğun işletmelerde insan kaynakları yönetiminin entelektüel sermayeye bakış açısını incelemiş ve işletmelerin çoğunun entelektüel sermaye kavramının bilincinde oldukları ve entelektüel sermayeyi geliştirerek mal ve hizmetlerine olumlu olarak yansıttıkları tespit edilmiştir.

Kurgun ve Akdağ (2013); entelektüel sermayenin ve örgüt performansının turizm sektöründeki otel işletmeleri üzerinde olan etkisini incelediklerinde örgüt performansıyla müşteri sermayesi arasında ve yapısal sermayeyle örgüt performansı arasında pozitif yönlü ve anlamlı ilişkiye rastlanmıştır. 
Shareef ve Davey (2005) listelenmiş 19 profesyonel İngiliz futbol kulübünün 2002 yılı için yıllık planlarında entelektüel sermaye raporlarını kalite ve kapsam yönünden ele almışlardır. Fakat bu İngiliz futbol kulüplerinin entelektüel sermaye bileşenlerini gerektiği kadar ayrıntılı bir şekilde raporlamadıkları belirtilmiştir. Gürel vd. (2012), Türkiye Süper Ligi futbol kulüpleri arasında borsada işlem görenlerin entelektüel sermayelerini incelemiş ve aralarında karşılaştırma yapmıştır. Sonuç olarak; Galatasaray Spor Kulübü'nün diğerlerine göre daha etkin olduğu ancak genel olarak tüm spor işletmelerinin entelektüel sermayelerini etkin yönetmelerinin gerekliliğine vurgu yapılmıştır. Geri (2012) ise çalışmasında Marmara Bölgesi'ndeki özel spor işletmelerinin entelektüel sermayeye bakış açılarını ve bu konuda uyguladıkları çalışmaları araştırmış, entelektüel sermayenin örgüt performansı üzerindeki etkisinin olumlu olduğu sonucuna varmıştır. Eduardo vd. (2014), kişisel refah ve bireysel refahla entelektüel sermaye arasındaki ilişkinin incelenmesine yardımcı olan bir taslak sunmak ve futbol antrenörlerinin kişisel entelektüel sermayesi için temsilci gösterge sistemini göstermek istemişlerdir. Araştırmanın sonucunda Avrupa'nın en iyi futbol kulüplerinin antrenörlerinin entelektüel sermaye girişimlerinin onların bireysel refahına olumlu etkisi olduğu belirlenmiştir.

Ünlü (2015), Türk prefabrik sektörü üzerinde yaptığı ve entelektüel sermayenin boyutları arasındaki ilişkiyi incelediği çalışmasında bu çalışmanın da sonuçlarına benzer olarak entelektüel sermaye boyutlarının birbirleriyle ilişki içerisinde olduğunu gözlemlemiştir.

Araştırmalar incelendiğinde farklı sektörlerde, entelektüel sermayenin önemini anlamak için yapılan çalışmalarda farklı ölçüm yöntemlerinin kullanıldığı görülmektedir. Bu yöntemler; Piyasa değeri\defter değeri, dengelenmiş skor kartı, knowcorp, Tobin-Q oranı, maddi olmayan varlıklar göstergesi, Skandia kılavuzu, maddi olmayan bilanço, ekonomik katma değer ve piyasa katma değeri, entelektüel sermaye endeksi, teknoloji broker, aktiflerin getiri oranı, piyasa aktifleştirmesi, direkt entelektüel sermaye, maddi olmayan varlıkların finans ölçümü, alıntı ağırlıklı patentler, insan kaynakları muhasebesi, K-Rating modeli, patent değeri ve bilgi sermayesi skor kartıdır (Aslanoğlu ve Zor, 2006; Çetin, 2005; Ünlü, 2015).

\section{Spor Sektöründe Entelektüel Sermayenin Ölçülmesinin İşletmelere Katkısı}

Çeşitli alt sektörleriyle birlikte her geçen gün büyüyen spor endüstrisinin paydaşları arasında spor malzemesi üreten işletmeler, stadyumlar, sahalar ve diğer spor tesisleri, spor kulüpleri, sporcular, amatör veya profesyonel spor ligleri yanında spor endüstrisinde büyük bir yer kaplayan spor ve sağlık işletmeleri (spor merkezleri) de yer almaktadır (Argan ve Katırcı, 2002: 3). Gelişen ve etkinleşen spor ekonomisi, eğlence, medya, müşterek bahis, spor malzemeleri, ulaşım, turizm, medya gibi diğer sektörlerle de dolaylı veya doğrudan ilişki içerisindedir (DPT, 2000: 9). Sporun ilişikli olduğu diğer sektörler ve bu sektörlerin de küresel dünyada dinamik bir yapıya sahip olması, spor işletmelerini içinde bulundukları bu sektörün özellikleri nedeniyle daha da rekabetçi olmaya zorlanmaktadır. Bu rekabetçi piyasa şartlarında hem bireysel hem de örgütsel anlamda performans kavramı dolayısıyla entelektüel sermaye kavramı ve ölçülmesinin önemi her geçen gün artmaktadır.

Bilgi günümüz işletmelerinin en önemli değeri haline gelmiş durumdadır (Demir, 2005: 77). Bilgi entelektüel sermaye unsurlarından "insan sermayesi" içinde yer almaktadır. Spor işletmeleri de sahip oldukları insan sermayesini doğru ve verimli kullanarak rekabet koşullarına uyum sağlayıp ayakta kalabilecekler ve rakiplerine karşı rekabet avantajı sağlayabileceklerdir.

Spor sektöründe taraftar sadakati, yetenekli oyuncular, yönetim ekibinin deneyimi gibi maddi olmayan varlıklar takım değerinin oluşturulmasında giderek daha da önem kazanmaktadır. Entelektüel sermayenin bileşenlerinin spor endüstrisi için de geçerli olduğu yapılan araştırmalarda görülmektedir. Çünkü spor endüstrisindeki işletmeler çoğunlukla maddi olmayan kaynaklara sahiptir. Mali raporlara dâhil olmamasına rağmen, spor kulübünün uzun vadeli başarısı, performansı, taraftar sadakati, kazanılan şampiyona sayısı, yetenekli oyuncu sayısı, yöneticilerin becerileri vb. değer yaratma sürecinde öne çıkmaktadır (Andrikopoulos ve Kaimenakis, 2006: 4). Bunların yanında bilgi, bilgi teknolojileri, bilgi sistemleri, markalar, lisans anlaşmaları, işletme adı, müşteri sadakati gibi maddi olmayan varlıklar spor işletmelerinin piyasa değerinin belirlenmesinde önemli faktörler olarak ele alınmaktadır. Sadece maddi varlıklara dayalı 
olarak hesaplanan işletme piyasa değerleri tespiti işletmelerin gerçek değerlerinin hesaplanmasında yeterli bulunmamaktadır.

Spor işletmelerinin hizmet yoğun çalışmalarından dolayı piyasa değerlerinin artmasında üretim yatırımlarından çok bilgi yatırımlarının daha önemli rol oynadığı işletmeler üzerinde yapılan çalışmalarla ortaya konulmuş ve spor işletmelerinde entelektüel sermaye kavramının öneminin fark edilmesine neden olmuştur. Müşteri odaklı olarak çalışmakta olan spor işletmelerinin varlıklarını sürdürmeleri; müşteri tarafından tercih edilmeleri, benimsenme, itibar görme, müşteri sadakati ve satın alınma süreçlerine bağlıdır. Bu süreçler entelektüel sermaye unsurlarından müşteri sermayesinin içinde yer almakta ve rekabet avantajındaki önemli faktör olarak belirtilmektedir. Özel spor işletmelerinin sahip oldukları insan, yapısal ve ilişkisel sermayelerinin örgüt performansı bakış açısıyla değerlendirilmesi gerekmektedir (Geri, 2012: 29).

Bugünün ekonomisinde bir işletmenin entelektüel varlıklarının değerinin maksimize edilmesinin, finansal varlıklarının değerinin maksimize edilmesinden daha büyük bir etkisi olacağı açıktır. Entelektüel sermaye gelecekteki nakit akışlarının temel kaynağıdır. Geleneksel bilançolarda entelektüel sermaye değerinin göz ardı edilmesi işletme değerinin eksik gösterilmesi; sermayenin yanlış tahsis edilmesi ve entelektüel sermaye yaratma faaliyetlerine düşük yatırım yapılması gibi sorunlara yol açabilir (Carrol ve Tansey, 2000: 305-306). Yatırımların doğru şekilde yapılamaması ve nakit akışlarının kontrol edilememesi spor sektöründeki işletmelerin performanslarında, büyümelerinde ve varlıklarını sürdürmelerinde sorun yaratabilir.

Genel olarak işletmelerde entelektüel sermayenin ölçülmesi, raporlanması ve analiz edilmesi, (NEBL 2001: 21-22) entelektüel sermayenin yönetiminin ne derece etkili olduğunun değerlendirmesinde yardımcı olmaktadır. Entelektüel sermaye, gerçekleşen faaliyet zamanındaki ve gelecekteki gelirin tahmin edilmesinde işletmeye yardımcı olmaktadır. İşletme için gerekli ve etkili yönetim yapılarının belirlenmesini sağlamaktadır. Yapılan raporlamalarla entelektüel sermaye kaynaklarını stratejik hedeflerle uyumlu hale getirerek işletme amaçlarıyla birleştirmeyi sağlamaktadır. İşletmede çalışanların entelektüel sermayeyle kârlılı̆a etkileri ilişkilendirilebilir. Çalışanların motivasyonlarını ve işletmeye olan bağlılıklarını yükseltmektedir. Müşteri memnuniyetini artırmaya yönelik yeni politikalar ve düzenlemeler getirilmesine yardımcı olmaktadır. Yöneticilerin örgütleri için değer yaratan maddi olmayan varlıkların korunması ve geliştirilmesi için yapılması gerekenlere odaklanmalarını sağlamaktadır.

Spor işletmelerinde entelektüel sermayenin raporlanması, hissedarlar, alacaklılar, çalışanlar, müşteriler, tedarikçiler ve politika oluşturan kurumlar gibi diğer menfaat sahipleri açısından da gerekli görülebilmektedir. Bu açıdan bakıldığında spor işletmeleri için entelektüel sermaye, sahip oldukları maddi olmayan kaynakların, paydaşların hedeflerinin başarılı bir şekilde ulaşmasını kolaylaştıracak bir bağ olarak tanımlanabilir(Andrikopoulos ve Kaimenakis, 2006: 3-4). Bu bağlamda entelektüel sermayenin ölçülmesi ve raporlanması diğer işletmelerde olduğu gibi spor işletmelerinde de önemli ve gerekli bir konu olarak yer almalıdır.

Spor sektörüne baktığımızda genel olarak başarı ve başarısızlık üzerine değerlendirmeler yapılmaktadır. Corrall ve Tansey'in de belirttiği üzere (2000); “Başarı işletmenin elinde bulundurduğu entelektüel sermayenin etkin yönetim kabiliyetiyle sağlanabilir". Spor işletmelerinin sürdürülebilir başarı ve rekabet gücü elde edebilmesi için entelektüel sermaye değerlerinin ölçülmesi, raporlanması ve değerlendirilmesi günümüz rekabetçi piyasa koşullarında önemli bir konu olarak vurgulanmaktadır. Bu bilgiler doğrultusunda yapılan bu çalışma spor işletmeleri yöneticilerinin entelektüel sermaye unsurlarına etkisi olan bilgi yönetimine yaklaşımları, entelektüel sermaye unsurlarını ve bu unsurlar arasındaki ilişkiyi değerlendirmeleri yönünden bir örnek niteliğindedir.

\section{Araştırmanın Varsayımları}

Bu çalışmada öncelikli olarak spor işletmesi yöneticilerinin bilgi paylaşımının, insan kaynaklarının, ilişkisel sermayenin ve yapısal sermayenin işletme için öneminin farkında oldukları varsayılmıştır. Bu varsayıma temel olan kaynak B-fit işletmeleri kurumsal iletişim direktörü ile yapılan görüşmeler ve işletmeler hakkında taranan dökümanlardır (https://b-fit.com.tr/tr). Ayrıca örneklem grubunun yanıtlama esnasında 
yeteri kadar motive oldukları ve anketi doğru ve tarafsız olarak yanıtladıkları varsayılmıştır. Anketin tam olarak anlaşılması ve belirsizlik olan kısımlarda araştırmacıların açıklama yapmalarııın sağlanması için öncelikle B-fit işletmelerinin genel merkezinden tüm işletme yöneticilerine açıklamalı bir e-postayla ulaşılmış, daha sonra da araştırmacılar tüm yanıtlayıcılarla telefonla iletişim kurmuştur. Ayrıca örnekleme dâhil olan yöneticilerin bilgi yönetiminin ve paylaşımının önemli olduğu ve entelektüel sermayenin alt boyutları arasında pozitif yönlü ilişki olduğu şeklinde değerlendirme yapacakları varsayılmıştır.

\section{Araştırmanın Yöntemi ve Uygulama}

Araştırma, Türkiye genelinde franchise şubeleri olan ve sadece kadınlara yönelik spor merkezi olarak faaliyet gösteren B-Fit spor işletmeleri üzerinde yapılmıştır. Tam sayım (doyma) örneklem seçim tekniği kullanılarak tüm işletmelere ulaşılmıştır. Toplamda 200 şubede görev yapmakta olan yöneticilere hem genel merkezden e-posta aracılığıyla hem de kişisel olarak e-posta ve telefon yoluyla ulaşılmış, 91 yönetici dönüş yapmıştır. Analizlere uygun olmayan iki anket dışarıda bırakılarak toplam 89 anket üzerinden veri analizi yapılmıştır.

Araştırmada veri toplama tekniği olarak anket ve doküman analizi yöntemlerinden yararlanılmıştır. Daha önce Ölçer ve Şanal (2007) tarafından Türkiye'deki büyük sanayi işletmelerine uygulanan ve entelektüel sermayenin boyutları olan insan sermayesi, yapısal sermaye ve ilişkisel sermayeyi ölçmek için kullanılan 47 maddelik anket sorusu sektörel özellikler dikkate alınarak uyumlaştırımış ve B-Fit işletmelerine uygulanmıştır. Anketin girişinde anketi nasıl doldurmaları gerektiği ve dikkat edilmesi gereken hususlar hakkında yönerge verilmiştir. Anketin ilk bölümünde demografik bilgilere, 2. bölümde bilgi yönetimine, 3. ve 4. bölümlerde insan sermayesine, 5 . ve 6 . bölümlerde yapısal sermayeye, 7. ve 8 . bölümlerde müşteri (ilişkisel) sermayesine yönelik ifadelere yer verilmiştir. Soruların yanıtları evet-hayır ve beşli Likert Ölçeği (1: Hiç Katılmıyorum, 2: Katılıyorum, 3: Ne Katılıyorum Ne Katılmıyorum, 4: Katılıyorum 5: Tamamen Katılıyorum) şeklinde alınmıştır.

Örneğe ulaşma oranı \%44 olarak gerçekleşmiştir. Tüm değerleme ve analizler 89 anket üzerinden yapılmıştır. Verilerin değerlendirilmesinde istatistiki veri değerlendirme programı kullanılmıştır. Entelektüel sermayenin bileşenleriyle ilgili toplam 28 ifadeye yönelik oluşturulan ölçeğin iç tutarlılık testinde Cronbach Alfa Katsayısı 0,956 olarak bulunmuştur. Bulunan bu sonuçlar neticesinde, araştırmada kullanılan ölçeğin güvenilir olduğu söylenebilir. Araştırmada ayrıca frekans analizi, faktör analizi ve korelasyon analizine yer verilmiştir.

Tablo 1. Güvenilirlik Analizi Sonuçları

\begin{tabular}{|l|c|}
\hline Faktör & $\boldsymbol{\alpha}$ \\
\hline İnsan Sermayesi & 0,896 \\
Yapısal Sermaye & 0,908 \\
Müşteri Sermayesi & 0,971 \\
Ölçeğin tamamı & 0,956 \\
\hline
\end{tabular}

\section{Araştırmadan Elde Edilen Bulguların Değerlendirilmesi}

\subsection{Ankete Katılan Yöneticilerin Demografik Özellikleriyle İlgili Bilgiler}

Araştırmaya katılan yöneticilerin demografik özellikleri Tablo 2'de gösterilmektedir. Sonuçlara bakıldığında anketi yanıtlayan yöneticilerin büyük çoğunlukla kadın olduğu $(\% 94,4)$ görülmüştür. İşletme özellikleri gereği kadın yoğun yöneticilerin olması beklenen bir sonuçtur. Anketi yanıtlayan yöneticilerin ağırlıklı olarak 31-40 yaş aralığında bulunduğu $(\% 43,8)$, eğitim düzeylerinin yoğun olarak lisans seviyesinde olduğu (\%50), spor sektöründe çalışılan sürenin ağırıklı olarak 1-5 yıl aralığında değiştiği $(\% 69,7)$ ve yine aynı işletmede yönetici olarak çalışılan sürenin de ağılıklı olarak 1-5 yıl arasında değiştiği $(\% 80,9)$ görülmüştür. 
Tablo 2. Yöneticilerin Demografik Özellikleri

\begin{tabular}{|c|c|c|c|c|c|}
\hline Yaş & $f$ & $\%$ & $\begin{array}{l}\text { Sektörde çalışma } \\
\text { süresi }\end{array}$ & $f$ & $\%$ \\
\hline $\begin{array}{l}20-25 \\
26-30 \\
31-40 \\
41-50 \\
51+ \\
\text { Yanitsız }\end{array}$ & $\begin{array}{l}5 \\
15 \\
39 \\
20 \\
2 \\
8\end{array}$ & $\begin{array}{l}5,7 \\
17 \\
43,8 \\
22,7 \\
2,3 \\
9,1\end{array}$ & $\begin{array}{l}1-5 \text { yıl } \\
6-10 \text { yıl } \\
11-15 \text { yıl } \\
16-20 \text { yıl }\end{array}$ & $\begin{array}{l}62 \\
23 \\
3 \\
1\end{array}$ & $\begin{array}{l}69,7 \\
26,1 \\
3,4 \\
1,1\end{array}$ \\
\hline Toplam & 89 & 100 & Toplam & 89 & 100 \\
\hline Cinsiyet & $f$ & $\%$ & $\begin{array}{l}\text { İş yerinde çalışma } \\
\text { süresi }\end{array}$ & $f$ & $\%$ \\
\hline $\begin{array}{l}\text { Kadın } \\
\text { Erkek } \\
\text { Yanıtsız }\end{array}$ & $\begin{array}{l}84 \\
1 \\
4\end{array}$ & $\begin{array}{l}94,4 \\
1,1 \\
4,5\end{array}$ & $\begin{array}{l}1-5 \text { yıl } \\
6-10 \text { yıl } \\
11-15 \text { yıl } \\
16-20 \text { yıl }\end{array}$ & $\begin{array}{l}70 \\
18 \\
1 \\
0\end{array}$ & $\begin{array}{l}78,7 \\
20,5 \\
1,1 \\
0\end{array}$ \\
\hline Toplam & 89 & 100 & Toplam & 89 & 100 \\
\hline Eğitim & $f$ & $\%$ & $\begin{array}{l}\text { İş yerinde yönetici } \\
\text { olarak çalışma süresi }\end{array}$ & $f$ & $\%$ \\
\hline $\begin{array}{l}\text { Lise } \\
\text { Ön lisans } \\
\text { Üniversite } \\
\text { Lisansüstü } \\
\text { Doktora } \\
\text { Yanıtsız }\end{array}$ & $\begin{array}{l}9 \\
11 \\
44 \\
12, \\
5 \\
1,1 \\
13\end{array}$ & $\begin{array}{l}10,2 \\
12,4 \\
50 \\
12,5 \\
11 \\
14,8\end{array}$ & $\begin{array}{l}1-5 \text { yıl } \\
6-10 \text { yıl } \\
11-15 \text { yıl } \\
16-20 \text { yıl }\end{array}$ & $\begin{array}{l}72 \\
16 \\
1 \\
0\end{array}$ & $\begin{array}{l}80,9 \\
18,2 \\
1,1 \\
0\end{array}$ \\
\hline Toplam & 89 & 100 & Toplam & 89 & 100 \\
\hline
\end{tabular}

\subsection{Yöneticiler Açışından Bilgi Yönetimi}

Bilgi paylaşımına yönelik sorulan sorulara göre anketi yanıtlayan yöneticilerin tamamı (\%100) sahip oldukları bilgiyi çalışanlarıyla paylaştıklarını belirtmişlerdir. Ancak; yine yöneticilerin büyük çoğunluğunun $(\% 83,1)$ "onuruma zarar verecek bir bilgiyi paylaşmam" sorusuna evet yanıtını vermesi, hata yaptıkları durumlarda onurlarına ve/veya statülerine zarar vereceği düşüncesiyle bunun açığa çıkmasını istemedikleri şeklinde yorumlanabilir. Anketi yanıtlayan yöneticilerin hemen hemen hepsi $(\% 98,9)$ bilgiyi işletmelerin rekabet gücünü etkileyen stratejik bir kaynak olarak gördüklerini belirtmişlerdir.

İşletmelerde bilgi paylaşımının olması ve bunun öneminin bilinmesi onları geleceğe taşıyacak önemli değerlerden bir tanesidir. Bu sayede bilgi bireylere özgü olmaktan çıkarak işletmeye mâl edilerek, işletmelerin yapısal sermayesi haline gelmiş olacaktır (Ölçer ve Şanal, 2007: 485, Özdemirci ve Aydın, 2008: 62).

Tablo 3. Yöneticilerin Bilgi Paylaşımı

\begin{tabular}{|l|c|c|c|c|}
\hline ifadeler & \multicolumn{2}{l|}{ Evet } & \multicolumn{2}{l|}{ Hayır } \\
\hline & $\mathbf{f}$ & $\%$ & $\mathbf{f}$ & \multicolumn{1}{c|}{$\%$} \\
\hline 1-Bilgimi çalışanlarla paylaşırım. & 89 & 100,0 & 0 & 0 \\
\hline $\begin{array}{l}\text { 2-Bilgi işletmelerin rekabet gücünü etkileyen stratejik } \\
\text { bir kaynaktır. }\end{array}$ & 88 & 98,9 & 1 & 1,1 \\
\hline 3-Onuruma zarar verecek bir bilgiyi paylaşmam. & 74 & 83,1 & 5 & 16,9 \\
\hline $\begin{array}{l}\text { 4-Yaptığım yanlışların başkaları tarafından } \\
\text { bilinmesinden endişelenirim. }\end{array}$ & 33 & 37,1 & 56 & 62,9 \\
\hline $\begin{array}{l}\text { 5-Hatalarımı gizleyemezsem işletme içindeki } \\
\text { karizmam sarsılır. }\end{array}$ & 16 & 18,0 & 73 & 82,0 \\
\hline 6-Bilgiyi paylaştığımda yükselmem engellenecektir. & 2 & 2,2 & 87 & 97,8 \\
\hline 7-Hatalarım bilinirse işten atılma riskim artar. & 15 & 16,9 & 74 & 83,1 \\
\hline
\end{tabular}




\subsection{Faktör Analizi}

Anket formunda yer alan insan sermayesi, yapısal sermaye ve müşteri sermayesi soruları faktör analizine tabi tutulmuştur. Uygunluk belirleme aşamasında; verilerin faktör analizine uygun olup olmadığını araştıran "Bartlett Küresellik Testi" (anlamlılık (sig.) değeri 0,000 ile uygun) ve faktör analizi için örneklem yeterliliğini ölçen "Kaiser-Meyer-Olkin Testi" (test değeri 0,850 - çok iyi) uygulanmıştır. Faktör analizi sonucu 3 faktörün entelektüel sermayeyi açıklama varyansı \%70 çıkmıştır. Bu faktörlerden birinci faktör olan insan sermayesinde 7 madde, ikinci faktör olan yapısal sermayede 6 madde ve üçüncü faktör olan müşteri sermayesinde 15 madde yer almıştır. Sonuç olarak veri setinin faktör analizine uygun olduğu belirlenmiştir (Kalaycl, 2017: 327-328).

Tablo 4. KMO ve Barlett Test Sonuçları

\begin{tabular}{|l|l|}
\hline Kaiser-Mayer-OklinMeasure of Sampling & 0,850 \\
\hline Barlett's Test of Approx.Ch & 2503,665 \\
Sphericity df & 0,378 \\
Sig. & 0,000 \\
\hline
\end{tabular}

\section{4. İnsan Sermayesi}

Yöneticilerin insan sermayesiyle ilgili Likert tipi sorulara verdikleri yanıtların analiz sonuçları Tablo 5'te, Evet/Hayır şeklindeki sorulara verdikleri yanıtların analizi Tablo 6'da gösterilmiştir.

Tablo 5'te yer alan verilere göre işletmeler iş görenlerini yetenek ve becerilerine göre $(\bar{x}=4,1910)$ seçmektedirler. Özellikle spor sektöründe bilgi, beceri ve yeteneğin yoğun olarak kullanıldığı düşünülürse buna dikkat edilerek seçilen iş görenlerin işletmenin insan sermayesi düzeyini arttıracağı düşünülmektedir. Bu sayede işletme sektör içinde rekabet avantajı kazanacaktır. Ayrıca anketi yanıtlayan yöneticilerin eğitim konusuna da gerekli önemi verdikleri bulgularda yer almaktadır. Eğitimlerde öğrendikleri bilgileri işletmelerine uygulayan iş görenler ödüllendirilmektedir $(\bar{x}=3,9775)$. Aynı şekilde Tablo 6 'da verilen ifadelerin yanıtları değerlendirildiğinde; yöneticiler çoğunlukla mesai saatleri içerisinde iş görenlerin eğitim almalarına olanak sağladıklarını $(\% 95,5)$ ve iş görenlerin gelişim ihtiyaçlarını karşılamakta büyük rol oynadıklarını $(\% 94,4)$ belirtmektedirler. Bu sonuçlarla Ölçer ve Şanal (2007)'nin yapmış olduğu çalışmayla benzer sonuçlara ulaşılmış, ankete katılan yöneticilerin eğitime verdikleri önemin yüksek seviyede olduğu görülmüştür. Bu da işletmedeki bilgi birikimini arttırmakta ve bu sayede insan sermayesinin gelişimine katkı sağlamaktadır şeklinde yorumlanabilir. Önerileri kabul edilen iş görenlerin ödüllendirilmeleri $(\bar{x}=3,9101)$ sayesinde motivasyonları da artacaktır (Altındağ ve Akgün, 2015: 293). Bunun yanında iş görenlerin kendi aralarında proje grupları oluşturmalarına destek verilmesi $(\bar{x}=3,9888)$ işbirliğiyle yenilik ve yaratıcılı̆̆ın desteklendiğini göstermektedir. İnsan sermayesinin en önemli ve öncelikli amacının yenilik ve yaratıcılığı teşvik etme olduğu düşünüldüğünde işletmede insan sermayesi doğru şekilde kullanılmış olacak ve işletmenin yapısal sermayesi de güçlenecektir (Ölçer ve Şanal, 2007: 486-488). Anketi yanıtlayan işletmelerde kalifiye iş görenleri işletme bünyesinde tutmak için gerekli şartların sağlanıyor olması $(\% 93,3)$ ve teknolojiye değil insana odaklanılıyor olması $(\% 97,8)$ önemli bir sonuçtur. Çünkü bilgi donanımına sahip iş görenlerle çalışılması ve onların gelişmelerine önem vererek bilgi birikimlerini geliştirmelerine olanak sağlayacak bir sistemin olması (\%91) günümüz rekabetçi piyasasında önemli bir avantaj sağlayacaktır. Ancak tüm bu olumlu yanlar yanında personel devir hızının beklenenden yüksek (\%60) olması dikkat edilmesi ve önem verilmesi gereken bir konudur (Yılmaz ve Halıcı, 2010: 95). Çünkü İ̧̧ görenlerin verimliliklerinin artması, işletmeye ve işin sürekliliğine olan güvenle doğru orantılıdır. 
Tablo 5. İnsan Sermayesi Betimsel ve Faktör Analiz Sonuçları

\begin{tabular}{|c|c|c|c|c|}
\hline & & statistik & Igiler & \\
\hline İfadeler & $\begin{array}{l}\mathbb{x} \\
\frac{\pi}{E} \\
\frac{\pi}{\pi} \\
\stackrel{0}{0} \\
0\end{array}$ & 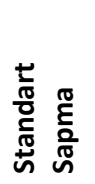 & $\frac{\frac{c}{\pi}}{\frac{c}{\frac{\pi}{\pi}}} \frac{n}{\frac{c}{\pi}}$ & 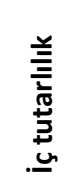 \\
\hline $\begin{array}{l}\text { 1-İş görenler yetenek ve becerilerine göre } \\
\text { değerlendirilip aralarından iyi olanlar } \\
\text { seçilmektedir. }\end{array}$ & 4,19 & 0,60 & \multirow{8}{*}{17,0} & \multirow{8}{*}{0,896} \\
\hline $\begin{array}{l}\text { 2-İş görenlerin bağlıı̆̆ını görmek için } \\
\text { değerlendirmeler yapıımaktadır. }\end{array}$ & 3,80 & 0,72 & & \\
\hline $\begin{array}{l}\text { 3-İş görenlerin, işletmeyi daha ileriye } \\
\text { götürmek amacıyla birbirleriyle rekabet } \\
\text { etmeleri için uygun ortam yaratılmaktadır. }\end{array}$ & 3,67 & 0,58 & & \\
\hline $\begin{array}{l}\text { 4-Önerisi kabul edilen iş görenler } \\
\text { ödüllendirilmektedirler. }\end{array}$ & 3,91 & 0,75 & & \\
\hline $\begin{array}{l}\text { 5-iş görenlerin kendi aralarında proje } \\
\text { grupları oluşturmalarına destek } \\
\text { verilmektedir. }\end{array}$ & 3,99 & 0,70 & & \\
\hline $\begin{array}{l}\text { 6-İş görenlere bir süre için başka } \\
\text { bölümlerde çalışma (rotasyon) izni } \\
\text { verilmektedir. }\end{array}$ & 3,74 & 0,63 & & \\
\hline $\begin{array}{l}\text { 7-Eğitim programlarında öğrendiklerini } \\
\text { işlerine uygulayan iş görenler } \\
\text { ödüllendirilmektedirler. }\end{array}$ & 3,98 & 0,76 & & \\
\hline TOPLAM & 3,90 & 0,80 & & \\
\hline
\end{tabular}

Tablo 6. İnsan Sermayesi için Evet/Hayır Soruları Frekans Analizi

\begin{tabular}{|l|c|c|c|c|}
\hline Ifadeler & \multicolumn{2}{|c|}{ Evet } & \multicolumn{2}{|c|}{ Hayır } \\
\hline & f & \% & f & $\%$ \\
\hline $\begin{array}{l}\text { 1-Kalifiye iş görenleri işletme bünyesinde tutmak için } \\
\text { gerekli şartlar sağlanıyor mu? }\end{array}$ & 83 & 93,3 & 5 & 5,6 \\
\hline $\begin{array}{l}\text { 2-Iş̧ görenlerin bilgi birikimlerini geliştirmeye olanak } \\
\text { sağlayacak bir sistem var mı? }\end{array}$ & 81 & 91,0 & 8 & 9,0 \\
\hline $\begin{array}{l}\text { 3-Sahip olunan bazı kaynaklar (bilgisayarlar, iletişim } \\
\text { sistemleri vs.) iş görenlerin kullanımına açık hale getiriliyor } \\
\text { mu? }\end{array}$ & 88 & 98,9 & 1 & 1,1 \\
\hline $\begin{array}{l}\text { 4-Mesai saatleri içerisinde öğrenme faaliyetlerine katılmak } \\
\text { için iş görenlere izin veriliyor mu? }\end{array}$ & 85 & 95,5 & 4 & 4,5 \\
\hline $\begin{array}{l}\text { 5-Yöneticiler iş görenlerin gelişim ihtiyaçlarını karşılamak } \\
\text { konusunda etkin rol alıyorlar mı? }\end{array}$ & 84 & 94,4 & 5 & 5,6 \\
\hline 6-Teknolojiye değil insana odaklanılıyor mu? & 87 & 97,8 & 2 & 2,2 \\
\hline 7-Bir öneri panosu veya kutusu var mı? & 75 & 84,3 & 14 & 15,7 \\
\hline 8-Personel devir hızı yüksek mi? & 54 & 60,7 & 35 & 39,3 \\
\hline
\end{tabular}

\subsection{Yapısal Sermaye}

Ankete katılan yöneticilerin yapısal sermayeyle ilgili Likert tipi sorulara verdikleri yanıtların analiz sonuçları Tablo 7'de, Evet/Hayır şeklindeki sorulara verdikleri yanıtların analiz sonuçları ise Tablo 8'de gösterilmiştir.

Buna göre, yapılan yeniliklerin tanıtılmasına $(\bar{x}=4,2022)$ olanak sağlandığı anlaşılmaktadır. İşletmeler piyasada rakiplerine karşı avantaj sağlayabilmek için yenilikler yapmak ve bunları da müşterilerine tanıtmak zorundadır. Bu sonuç yenilik yapma konusunda ve yenilikleri tanıtma konusunda işletmelerin çalıştıklarını 
göstermektedir (Oktay, 2006: 140). Analiz sonuçlarına göre işletmeler sahip olunan veri tabanını yenilemekte $(\bar{x}=4,0562)$, iş görenler sahip oldukları bilgiyi işletmeye aktararak işletme veri tabanı oluşturmakta $(\bar{x}=4,1124)$ ve gerekli bilgiye veri tabanlarından hızı bir şekilde ulaşmaktadır $(\bar{x}=4,1236)$. Bunun yanında yöneticilerin büyük oranının $(\% 97,8)$ yararlı ve intiyaç duyulan bilgiyi tutmaya, depolamaya ve dağıtmaya yönelik bir sisteminin olduğundan bahsetmesi işletme içi hızlı bilgi paylaşımını sağlayacak bir sistemin neredeyse işletmelerin tamamında $(\% 93,3)$ var olması işlerin zamanında ve doğru şekilde tek seferde yapılmasını sağlayacaktır. Bununla birlikte iş görenleri öğrendiklerini paylaşmaya özendiren bir kültürel yapıya büyük oranda $(\% 92,1)$ sahip olmaları insan sermayesiyle yapısal sermayenin geliştirildiğinin bir göstergesidir. Verilen hizmetlerin ve müşterilerle ilgili bilgilerin neredeyse tüm işletmelerde kayıt altına alınıyor olması $(\% 96,6)$ ve müşterilere veya tedarikçilere ilişkin bilgilerin veri tabanlarında düzenleniyor olması $(\% 91,0)$ yapısal sermayenin önemli bir unsuru olan veri tabanı oluşturma işlemini doğru ve başarılı şekilde kullandıklarını göstermektedir. İşletmelerin veri tabanı oluşturarak iş görenlerin sahip olduğu bilgiyi yapısal sermayeye etkin şekilde dönüştürmüş olmaları müşteri portföylerini etkin şekilde yönetmelerini sağlayacaktır. Bunların yanında bilgilerin nerede bulunduğunu gösteren haritaların daha çok $(\% 59,6)$ işletmede yer alması geliştirilmesi gereken unsurlardandır. Bu uygulamaların arttırılmasıyla işletmelerde yapılan hataların belirlenmesi ve tekrarının önlenmesi belirgin şekilde verimlilik artışı sağlayacaktır (Özdemirci ve Aydın, 2008: 62). Verimlilik artışı, müşteri memnuniyetini arttıracak yani işletmenin başarısı için iyi bir avantaj sağlanmış olacaktır.

Starovic ve Marr (2004) örgütlerde bilgi yönetiminin mümkün olmadığını, bilginin paylaşılmasını sağlayan ancak yönetilmesi oldukça güç olan kültürün yönetilebileceğini savunmaktadır. Bilgi açık ve örtük bilgi olarak belirmekte ve açık bilgi anlaşılabilir ve öğretilebilir iken, örtük bilgi ise gözlemlenemeyen, karmaşık ve öğretilemeyen bir yapıdadır. Açık bilgi yönetimsel ve teknik prosedürlerde yer alabilmekte, ancak örtük bilgi iş görenlerin zihinlerinde ve birbirleriyle aralarındaki ilişkilerde var olmaktadır. Bu açıdan değerlendirildiğinde bilgi yönetimini de içeren kültürel yapının önemi ön plana çıkmaktadır.

Tablo 7. Yapısal Sermaye Betimsel ve Faktör Analiz Sonuçları

\begin{tabular}{|c|c|c|c|c|}
\hline \multirow[b]{2}{*}{ ifadeler } & \multicolumn{4}{|c|}{ İstatistiki Bilgiler } \\
\hline & $\frac{\stackrel{\pi}{\frac{\pi}{\pi}}}{\frac{\pi}{\pi}} \underset{\stackrel{\pi}{t}}{\square}$ & 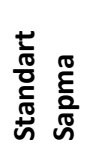 & 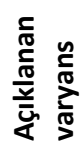 & 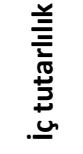 \\
\hline $\begin{array}{l}\text { 1-iş görenlerin işlerinde yardımcı olabilecek } \\
\text { uzmanlara zamanında ulaşabilmesi } \\
\text { sağlanmaktadır. }\end{array}$ & 4,02 & 0,75 & \multirow{7}{*}{15,6} & \multirow{7}{*}{0,908} \\
\hline $\begin{array}{l}\text { 2-Sahip olunan veri tabanı sürekli olarak } \\
\text { yenilenmektedir. }\end{array}$ & 4,06 & 0,79 & & \\
\hline $\begin{array}{l}\text { 3-Üretilen yeniliklerin tanıtılması } \\
\text { sağlanmaktadır. }\end{array}$ & 4,20 & 0,82 & & \\
\hline $\begin{array}{l}\text { 4-Gerekli olunan bilgiye hızlı bir şekilde } \\
\text { ulaşılmaktadır. }\end{array}$ & 4,12 & 0,78 & & \\
\hline $\begin{array}{l}\text { 5-iş görenler sahip olduğu bilgiyi } \\
\text { işletmelere aktarıp, işletme veri tabanı } \\
\text { oluşturabilmektedir. }\end{array}$ & 4,11 & 0,66 & & \\
\hline $\begin{array}{l}\text { 6-isş görenler kendi kariyer planlarında } \\
\text { sorumluluk almaları teşvik edilmektedir. }\end{array}$ & 4,26 & 0,51 & & \\
\hline TOPLAM & 4,13 & 0,66 & & \\
\hline
\end{tabular}


Tablo 8. Yapısal sermayesi için Evet/Hayır Soruları Frekans Analizi

\begin{tabular}{|l|c|c|c|c|}
\hline Ifadeler & \multicolumn{2}{|c|}{ Evet } & \multicolumn{2}{c|}{ Hayır } \\
\hline & f & $\%$ & f & $\%$ \\
\hline $\begin{array}{l}\text { 1-Örgüt içi hızlı bilgi paylaşımını sağlayacak bir sistem var } \\
\text { mı? }\end{array}$ & 83 & 93,3 & 6 & 6,7 \\
\hline $\begin{array}{l}\text { 2-Rakiplere ilişkin bilgiler bilgi veri tabanında düzenleniyor } \\
\text { mu? }\end{array}$ & 42 & 47,2 & 47 & 52,8 \\
\hline 3-Hizmetle ilgili bütün bilgiler kayıt altına alınıyor mu? & 86 & 96,6 & 3 & 3,4 \\
\hline $\begin{array}{l}\text { 4-Yararlı ve ihtiyaç duyulan bilgiyi tutmaya, depolamaya ve } \\
\text { dağıtmaya yönelik bir sistem var mı? }\end{array}$ & 87 & 97,8 & 2 & 2,2 \\
\hline 5-Sürekli bilgi gelişimini sağlayacak bir sistem var mı? & 80 & 89,9 & 9 & 10,1 \\
\hline 6-Bilgilerin nerede bulunduğunu gösteren haritalar var mı? & 53 & 59,6 & 36 & 40,4 \\
\hline 7-Hizmet gelişiminini sağlayan programlar var mı? & 66 & 74,2 & 23 & 25,8 \\
\hline $\begin{array}{l}\text { 8-İş görenleri öğrendiklerini paylaşmaya özendiren bir } \\
\text { kültürel yapı var mı? }\end{array}$ & 82 & 92,1 & 7 & 7,9 \\
\hline 9-i̇yi bir iletişim sistemi var mı? & 87 & 97,8 & 2 & 2,2 \\
\hline 10-Düzenli olarak takip edilen süreli yayınlar var mı? & 55 & 61,8 & 34 & 38,2 \\
\hline $\begin{array}{l}\text { 11-Teknolojik gelişmelerin işletme faaliyetlerine kısa sürede } \\
\text { yansıması sağlanıyor mu? }\end{array}$ & 72 & 80,9 & 17 & 19,1 \\
\hline $\begin{array}{l}\text { 12-Müşteriler veya tedarikçilere ilişkin bilgiler bilgi veri } \\
\text { tabanında düzenleniyor mu? }\end{array}$ & 81 & 91,0 & 8 & 9,0 \\
\hline $\begin{array}{l}\text { 13-Rakipler tarafından piyasaya sunulması muhtemel } \\
\text { yeniliklerimiz patentle koruma altına alınmakta mıdır? }\end{array}$ & 56 & 62,9 & 33 & 37,1 \\
\hline
\end{tabular}

\subsection{Müşteri (ilişkisel) Sermayesi}

Ankete katılan yöneticilerin müşteri sermayesiyle ilgili Likert tipi sorulara verdikleri yanıtların analiz sonuçları Tablo 9'da, Evet/Hayır şeklindeki sorulara verdikleri yanıtların analiz sonuçları ise Tablo 10'da gösterilmiştir.

Buna göre verilen hizmetler hakkında müşterilerin bilgilendiriliyor olması $(\bar{x}=4,4270)$, işletmelerin müşterilerle etkin bir iletişimlerinin olması $(\bar{x}=4,4157)$, müşterilere işletmeyle ilgili bilgilerin sunulması $(\bar{x}=4,3371)$ ve müşterilerin beklentilerini sürekli olarak değerlendirip, ona uygun hizmet sunulmasıyla $(\bar{x}=4,2360)$ ilgili ortalama değerler müşteri sermayesinin üzerinde çalışllan örneklem düzeyinde etkin bir şekilde yönetiliyor olduğunu göstermektedir. Bununla birlikte işletmelerin mevcut müşterilerinin uzun vadede korunması için bir politikaya sahip olması $(\% 89,9)$, internet üzerinden mevcut ve potansiyel müşterilerine yönelik bir bilgi formlarının olması $(\% 83,1)$, internet üzerinden müşterilerine yönelik online hizmetin verilmesi $(\% 71,9)$ ve müşterilere özel hizmet geliştirilmesi $(\bar{x}=4,0225)$ müşteriye verilen değer ve önemin göstergesi olarak düşünülmektedir. Bu sayede de müşterilerin işletmeye olan bağlılıkları artmakta ve müşteri sermayeleri güçlenmektedir. Tekrarlanan üyelik sayısı oranının yüksek $(\% 83,1)$ olması da bunun önemli bir göstergesidir.

Elde edilen bulgular doğrultusunda markalarına karşı kamuoyunda belirgin bir imajın var olması $(\bar{x}=4,26)$ ve satış sonrası hizmet için bir bölümün $(\% 86,5)$ olması markaya verilen önemi ve bu markanın değer kazanması için çaba gösterildiğini ifade etmektedir. Bu da işletmenin müşteri sermayesini etkin kullanma çabasında olduğunu göstermektedir. Müşteri tatmin derecesinin sürekli olarak ölçülmesi $(\bar{x}=4,1236)$ ve müşterilerle uzun süreli iletişim kurabilmek için etkili iletişim sisteminin kullanılıyor olması $(\bar{x}=4,2809)$ ve müşterilerin işletmeye olan bağlılık düzeyini belirlemek için değerlendirmeler yapılması $(\bar{x}=4,0674)$ sorunların belirlenmesi ve gerekli önlemlerin alınması için önemli uygulamalardır. Bu sayede mevcut müşteri sermayesi daha da geliştirilmiş olacak ve rakiplere karşı avantaj sağlanmış olacaktır. Analiz yapılan işletmelerin bunu büyük ölçüde başarmış olduklarının göstergesi de hizmetlerinden şikâyetçi olan müşteri oranının çok az (\%4) olmasıdır. Bunlara karşılık internet üzerinden müşterilerine yönelik online hizmet olmayan işletme oranının (\%27) olması geleceğe yönelik planlarında online hizmetler yönünde çalışmalarda bulunmalarını ve bu yönde yenilikler yapmalarını gerektirmektedir. 
Entelektüel Sermaye Unsurları Arasındaki iliş̧ki ve Bu Unsurların Yönetilmesi: B-fit Iş̧letmeleri Örneği

Tablo 9. Müşteri Sermayesi Betimsel ve Faktör Analiz Sonuçları

\begin{tabular}{|c|c|c|c|c|}
\hline \multirow[b]{2}{*}{ ifadeler } & \multicolumn{4}{|c|}{ İstatistiki Bilgiler } \\
\hline & $\begin{array}{l}\mathbb{\Xi} \\
\stackrel{\pi}{0} \\
\frac{E}{\pi} \\
\frac{\pi}{\pi} \\
0\end{array}$ & 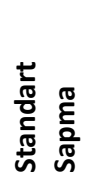 & 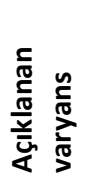 & 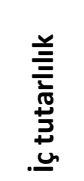 \\
\hline 1-Markamıza karşı kamuoyunda belirgin bir imaj vardır. & 4,27 & 0,81 & \multirow{15}{*}{37,4} & \multirow{16}{*}{0,971} \\
\hline 2-Hizmetler hakkında müşteriler bilgilendirilmektedir. & 4,43 & 0,85 & & \\
\hline 3-Tedarikçilerimizle etkin bir iletişimimiz vardır. & 4,21 & 0,70 & & \\
\hline 4-Müşterilerimizle etkin bir iletişimimiz bulunmaktadır. & 4,42 & 0,91 & & \\
\hline 5-Müşterilere işletme ile ilgili bilgiler sunulmaktadır. & 4,34 & 0,80 & & \\
\hline $\begin{array}{l}\text { 6-Müşterilerin beklentilerini sürekli olarak değerlendirip, ona } \\
\text { uygun ürün veya hizmet geliştirilmektedir. }\end{array}$ & 4,24 & 0,84 & & \\
\hline $\begin{array}{l}\text { 7-Müşteri ve tedarikçilerden alınan bilgiler işletme içinde } \\
\text { düzenli ve sürekli biçimde paylaşılmaktadır. }\end{array}$ & 4,32 & 0,82 & & \\
\hline $\begin{array}{l}\text { 8-Rakipler ile rekabet etmede, sahip olduğumuz bilgi etkili } \\
\text { bir şekilde kullanılmaktadır. }\end{array}$ & 4,06 & 0,76 & & \\
\hline 9-Müşteri tatmin derecesi sürekli olarak ölçülmektedir. & 4,12 & 0,84 & & \\
\hline $\begin{array}{l}\text { 10-Müşterilerle uzun süreli iletişim kurabilmek için etkili } \\
\text { iletişim sistemi kullanılmaktadır. }\end{array}$ & 4,28 & 0,82 & & \\
\hline $\begin{array}{l}\text { 11-Müşterilerin işletmemize olan bağlılık düzeyini belirlemek } \\
\text { için değerlendirmeler yapılmaktadır. }\end{array}$ & 4,07 & 0,72 & & \\
\hline $\begin{array}{l}\text { 12-Müşteri ve tedarikçilere karşı zayıfıklarımızı ortadan } \\
\text { kaldırmak amacıyla çalışmalar yapıımaktadır. }\end{array}$ & 4,07 & 0,73 & & \\
\hline 13-Müşterilere özel ürün ve hizmet geliştirilmektedir. & 4,02 & 0,73 & & \\
\hline 14-Müşteri iletişim hattı etkin bir şekilde kullanılmaktadır. & 4,23 & 0,79 & & \\
\hline $\begin{array}{l}\text { 15-Kullanılan marka ve logoların piyasada değer kazanması } \\
\text { için çaba gösterilmektedir. }\end{array}$ & 4,37 & 0,76 & & \\
\hline TOPLAM & 4,23 & 0,73 & & \\
\hline
\end{tabular}

Tablo 10. Müşteri Sermayesi Evet/Hayır Soruları Frekans Analizi

\begin{tabular}{|l|c|c|c|c|}
\hline Iffadeler & \multicolumn{2}{|c|}{ Evet } & \multicolumn{2}{|c|}{ Hayır } \\
\hline & f & $\%$ & f & $\%$ \\
\hline $\begin{array}{l}\text { 1-Bir ürün veya hizmette müşterilerin ne istediğini rakiplerden daha } \\
\text { iyi kavramak için oluşturulmuş bir metoda sahip misiniz? }\end{array}$ & 67 & 75,3 & 21 & 23,6 \\
\hline 2-Hizmetlerinizden şikâyetçi olan müşteri oranı yüksek mi? & 4 & 4,5 & 84 & 94,4 \\
\hline $\begin{array}{l}\text { 3-Satış sonrası hizmet için bir bölümünüz var mı? (üyelikten } \\
\text { vazgeçme durumunda para iadesi, üyelik dondurma hizmetleri gibi) }\end{array}$ & 77 & 86,5 & 11 & 12,4 \\
\hline 4-Tekrarlanan üyelik sayısı oranınız yüksek mi? & 74 & 83,1 & 14 & 15,7 \\
\hline $\begin{array}{l}\text { 5-Mevcut müşterilerinizin uzun vadede korunması için bir politikaya } \\
\text { sahip misiniz? }\end{array}$ & 80 & 89,9 & 8 & 9,0 \\
\hline $\begin{array}{l}\text { 6-internet üzerinden mevcut ve potansiyel müşterilerinize yönelik } \\
\text { bir bilgi formu var mı? }\end{array}$ & 74 & 83,1 & 14 & 15,7 \\
\hline $\begin{array}{l}\text { 7-Internet üzerinden müşterilerinize yönelik online hizmetiniz var } \\
\text { mı? }\end{array}$ & 64 & 71,9 & 24 & 27,0 \\
\hline
\end{tabular}

\subsection{Faktörlerarası Korelasyon Analizleri}

Araştırmanın varsayımlarında yer alan entelektüel sermaye faktörleri arasında pozitif yönlü ilişkiyi test etmek amacıyla faktörlerinin birbirleri arasındaki ilişkiye (korelasyon) bakılmıştır. Analiz sonuçları Tablo $11^{\prime}$ de görülmektedir. 
Tablo 11. Faktörlerarası Korelasyon

\begin{tabular}{|l|c|c|c|}
\hline Spearman's rho & $\begin{array}{c}\text { Insan } \\
\text { Sermayesi }\end{array}$ & $\begin{array}{c}\text { Yapısal } \\
\text { Sermaye }\end{array}$ & $\begin{array}{c}\text { Müşteri } \\
\text { Sermayesi }\end{array}$ \\
\hline Insan Sermayesi & 1,000 & & \\
\hline Yapısal Sermaye & $0,414^{* *}$ & 1,000 & \\
\hline Müşteri Sermayesi & $0,465^{* *}$ & $0,492^{* *}$ & 1,000 \\
\hline
\end{tabular}

** 0,01 anlamlılık düzeyinde $(p<0,01)$

Yapılan analizler sonucunda faktörler arasında araştırmanın varsayımlarına da uygun olarak orta derecede anlamlı ilişkinin olduğu görülmüş ve bu doğrultuda boyutlar arası ilişkisel modeller tanımlanmıştır.

Buna göre;

- Insan sermayesi düzeyi yükseldikçe, yapısal sermaye düzeyi de yükselmektedir.

- Yapısal sermaye düzeyi yükseldikçe, müşteri sermayesi düzeyi de yükselmektedir.

- İnsan sermayesi düzeyi yükseldikçe, müşteri sermayesi düzeyi de yükselmektedir.

\section{Sonuç ve Değerlendirme}

Spor İşletmeleri küresel rekabet ortamında güçlerini artırmak, piyasada etkin olabilmek ve yeni stratejiler geliştirebilmek için ellerindeki en önemli rekabet üstünlüğü yaratan kaynak olan entelektüel sermayeyi ortaya çıkarmak ve ölçmek durumundadır. Bu nedenle, spor işletmelerindeki yöneticilerin; öncelikle çalışanlarının bilgi, beceri ve yeteneklerini geliştirici uygulamalar yapmaları gerekecektir. Ayrıca örgüt içinde öğrenmeyi özendirici bir yönetim anlayışı benimsenmesi entelektüel sermaye birikimi ve gelişimi için önemli bir husustur.

Türkiye genelinde yaklaşık 200 tane şubesi olan B-fit işletmeleri üzerinde yapılan çalışmada çalışmaya yanıt veren 89 işletme yöneticisi açısından bakıldığında insan kaynaklarına önem verildiği, yapısal sermayeyi geliştirmek adına çalışıldığı, ilişkisel sermayenin ana paydaşları olan müşterilerle etkin iletişim kurulduğu söylenebilir. Alan yazında entelektüel sermaye unsurları olarak belirtilen bu üç unsurun genel olarak değerlendirilmesi sonucunda ise spor sektöründe hizmet yoğun olarak çalışan B-fit işletmelerinde entelektüel sermaye yönetimine önem verildiği söylenebilir. Ancak entelektüel sermaye yönetimine önem verilmesine rağmen bilgi paylaşımı konusunda yöneticilerin tereddütlerinin olduğu da gözden kaçırılmamalıdır. Bilgi paylaşımını kontrol etmek ve yönetmek güç olduğundan (Starovic ve Marr, 2004), bilginin paylaşımına uygun zemin hazırlayacak olan örgütsel kültüre önem vermek gerekmektedir. Çünkü bilginin gözle görülebilir olmayan kısımlarını paylaşmaya hazır ve gönüllü olmak, iş görenlerin bu paylaşımı hissedilebilecekleri bir örgüt kültürü ortamında mümkün olacaktır.

Araştırma sonucunda entelektüel sermayenin alt boyutları olan insan sermayesi, yapısal sermaye ve müşteri sermayesi arasında pozitif yönlü ve orta derecede güçlü ilişki belirlenmiştir. Stratejik yönetim açısından entelektüel sermayenin varlığından söz edebilmek için; bu üç alt boyutun bir arada değerlendirilmesi gerektiği spor işletmeleri tarafından göz önünde bulundurulmalıdır. Spor işletmeleri rekabet gücü elde edebilmeleri için maddi kaynaklarının yanında sahip oldukları entelektüel sermaye unsurlarının yönetimine de gereken önemi vermelidir (Görmüş, 2009: 70). İşletme bünyesinde var olan entelektüel sermaye unsurlarının güçlendirilmesi yanında iyi yönetilebilmesi de dikkat edilecek hususlardandır (Geri, 2012: 29; Özaydın vd., 2015: 6654). Örgütlerde insan sermayesini oluşturan çalışanların bilgi düzeyleri, özellikleri, girişimcilik düzeyleri gibi hususlar (Guthrie vd., 2007) yapısal sermayenin yapı taşı olarak nitelendirilebilecek örgüt kültürüne uzun vadede temel oluşturabilecek özelliklerdir. Yapısal sermayenin iyi yönetiliyor olmasının da müşteri sermayesini olumlu yönde etkileyeceği açıktır. Bu nedenle entelektüel sermaye unsurlarını bir yapıyı oluşturan ve birbiri üzerinde etkiye sahip olan alt yapılar olarak değerlendirmek yerinde olacaktır. Bu alt yapılardan herhangi birindeki zayıf ya da eksik yön diğerlerini de etkileme olasıllı̆̆na sahiptir. 
Birer spor işletmesi olarak faaliyet gösteren spor kulüplerinde entelektüel sermaye yönetiminin incelenmesiyle örgüt performansı, iş gören kariyer gelişimi, örgütsel bağlılık ve marka değeri yaratma gibi işletmeyle ilgili diğer önemli konuların ilişkilendirilmesi ve derinlemesine bilgi sağlayacak nitel analiz tekniklerinin de kullanılması entelektüel sermayenin öneminin ve sağlayacağı faydaların anlaşılması açısından yerinde olacaktır. Ayrıca ileride yapılacak çalışmalarda bu araştırma özelindeki durumlardan örneklemdeki işletmelerin sadece kadınlara yönelik hizmet veriyor olması ve franchise şeklinde çalışılması nedeniyle yönetim süreçlerinin ortak olması da göz önünde bulundurulabilir.

\section{Teşekkür}

Araştırmacı, verilerin sağlıklı bir şekilde toplanarak araştırmanın verimli bir şekilde yürütülmesinde izin ve desteklerini esirgemeyen ve bilimsel çalışmanın oluşmasına zemin sağlayan B-fit Kadınların Spor ve Yaşam Merkezi'ne ve araştırmanın ilk şekli olan bildiri kısmından beri desteklerini esirgemeyen yüksek lisans öğrencileri Özlem Işık Inan, Tanay Bozdemir ve Meltem Karaaslan'a teşekkür etmektedir.

\section{Son Notlar}

* Bu çalışma 15-17 Kasım 2017 tarihlerinde Antalya-Türkiye'de düzenlenen 15. Uluslararası Spor Bilimleri Kongresi'nde özet olarak sunulan bildirinin gözden geçirilmiş ve genişletilmiş halidir.

\section{Kaynaklar}

Abeysekera, I., \& Guthrie, J. (2004). How is intellectual capital being reported in a developing nation? Research in Accounting in Emerging Economies, Supplement 2: Accounting and Accountability in emerging and transition economies, 2004, 149-169. Available at SSRN: https://ssrn.com/abstract=2322291

Alagöz, A. \& Özpeynirci, R. (2007).Bilgi toplumunda entelektüel varlıklar ve raporlanması. Afyon Kocatepe Üniversitesi i.i.B.F. Dergisi, 9(11),167-184.

Altındağ, E. \& Akgün, B. (2015). Örgütlerde ödüllendirmenin iş gören motivasyonu ve performansı üzerine etkisi. Mustafa Kemal Üniversitesi Sosyal Bilimler Enstitüsü Dergisi, 12(30), 281-297.

Andrikopolous, A. \& Kaimenakis, N. (2006). Introducing intellectual capital analysis to soccer club management: An integrated map of intangible sources of value. Available at SSRN: http://ssrn.com/abstract=907675

Argan, M., \& Katırcı, H. (2002). Spor pazarlaması. Ankara: Nobel Yayın Dağıtım.

Arıkboğa, F. Ş. (2003). Entelektüel sermaye. İstanbul: Derin Yayınları.

Aslanoğlu, S., \& Zor, I. (2006). Bilgi varlıklarının değerlemesi: Entelektüel sermaye ölçüm ve değerleme modelleri. Muhasebe ve Finansman Dergisi, 29, 152-165.

Bontis, N. (2001). Assessing knowledge asset: A review of the models used to measure intellectual capital. IJMR: International Journal of Management Reviews, 3(1), 41-60.

Bozbura F. T., \& Toraman, A. (2004). Türkiye'de entelektüel sermayenin ölçülmesi ile ilgili model çalışması ve bir uygulama. İstanbul Teknik Üniversitesi Dergisi, 3(1), 55-56.

Carroll, R. F., \& Tansey, R. R. (2000). Intellectual capital in the new economy: Its meaning, measurement and management for enhancing quality. Journal of Intellectual Capital, 1(4), 296-311.

Chang, S., Chen, S., \& Lai, J. (2008). The effect of alliance experience and intellectual capital on the value creation of international strategic alliances. Omega, 36(2), 298-316.

Çalışkan, M. M. T. (2015). Bilgi ekonomisinde entelektüel sermaye: Borsa İstanbul'da bankacılık sektörü uygulaması. Yönetim ve Ekonomi Araştırmaları Dergisi, 13(3), 121-137.

Çetin, A. (2005). Entelektüel sermaye ve ölçülmesi. Marmara Üniversitesi i.i.B.F. Dergisi, 20(1), 359-378.

Demir, Ö. (2005). Entelektüel sermayenin işletmelerin piyasa değerlerine olan etkisi. Doğu Anadolu Bölgesi Araştırmaları, 3(2), 77-82. 
DPT Sekizinci Beş yıllık Kalkınma Planı, Beden Eğitimi, Spor ve İstanbul Olimpiyatları (2000). Özel İhtisas Komisyon Raporu, Ankara: DPT Yayınları.

Eduardo, T., Luliia, N., \& Marina, O. (2014). Personal welfare and intellectual capital: The case of football coaches. Journal of Intellectual Capital, 15(1), 189-202.

Edvinsson, L. (1997). Developing intellectual capital at Skandia. Long Range Planning, 30(3), 366-372.

Geri, S. (2012). İşletmelerde entelektüel sermaye, spor işletmelerine yansıması ve Marmara Bölgesinde bir araştırma. Selçuk Üniversitesi Beden Eğitimi ve Spor Dergisi, 14(1), 22-30.

Görmüş, A. Ş. (2009). Entelektüel sermaye ve insan kaynakları yönetiminin artan önemi. Afyon Kocatepe Üniversitesi i.i.B.F. Dergisi, 11(1), 57-75.

Guthrie, J., Cuganesan, S., \& Ward, L. (2007). Extended performance reporting: Evaluating corporate social responsibility and intellectual capital management. Issues in Social and Environmental Accounting, 1(1), 1-25.

Gürel, P., Dağlı Ekmekçi, Y. A., \& Küçükkaplan, ì. (2012). Measuring intellectual capital for football clubs: Evidence from Turkish first division football league. Pamukkale Journal of Sport Sciences, 4(1), 36-47.

Hobikoğlu Haykır, E. (2011). Entelektüel sermayenin önemi, sınıflandırılması ve ölçme yöntemleri: Kurumsal bir çerçeve. istanbul Üniversitesi Sosyal Bilimler Dergisi, 1, 86-99.

Kalaycı, Ş. (Ed.) (2017). SPSS uygulamalı çok değişkenli istatistik teknikleri. Ankara: Dinamik Yayınları.

Kanıbir, H. (2004). Yeni bir rekabet gücü kaynağı olarak entelektüel sermaye ve organizasyonel performansa yansımaları. Havacılık ve Uzay Teknolojileri Dergisi, 1(3), 77-85.

Kayalı, C. A., Yereli, A.N. \& Ada, Ş. (2007). Entelektüel katma değer katsayısı yöntemi kullanılarak entelektüel sermayenin firma değeri üzerindeki etkisinin belirlenmesine yönelik bir araştırma. Celal Bayar Üniversitesi i.i.B.F. Yönetim ve Ekonomi Dergisi, 14(1), 67-90.

Kurgun, O. A., \& Akdağ, G. (2013). Entelektüel sermaye ve örgüt performansı ilişkisi: Akdeniz Bölgesindeki otel işletmelerinde bir araştırma. NEÜ Sosyal Bilimler Enstitüsü Dergisi, 2, 155-176.

Mladkova, L., (2013). Intellectual capital and the system of organizational management. Proceedings of the $5^{\text {th }}$ European Conference on Intellectual Capital, University of Basque Country, Bilbao, Spain, 290-296.

Muş, A. (2010). Bilgi Yoğun işletmelerde insan kaynakları yönetiminin entelektüel sermayeye bakış açısı. Marmara Üniversitesi Sosyal Bilimler Enstitüsü, Yayınlanmamış Doktora Tezi, İstanbul.

NEBL_Invisible Value, (2001). The case for measuring and reporting intellectual capital. Business Competitiveness Division, Canberra, p.21-22. www.industry.gov.au/library/NEBL-Intellectual__apital.pdf (Erişim tarihi: 09.10.2017).

Nuzumlalı, F.Ö. (2008). Bankalarda kurumsal yönetim - Entelektüel sermaye ilişkisi ve bir araştırma. Selçuk Üniversitesi Sosyal Bilimler Enstitüsü, Yayınlanmamış Doktora Tezi, Konya.

Oktay, E. (2006). Stratejik yönetim sürecinde performans geliştirmenin bir aracı olarak dış kaynak kullanımı: İmalat sanayiinde bir uygulama. Selçuk Üniversitesi Sosyal Bilimler Enstitüsü, Yayınlanmamış Doktora Tezi, Konya.

Ölçer, F., \& Şanal, M. (2007). İ̧̧letmelerde entelektüel sermaye yönetimi. Çukurova Üniversitesi Sosyal Bilimler Enstitüsü Dergisi, 16(1), 479-500.

Özaydın, M. M., İlhan, E. \& Bayrak, M. R. (2015). entelektüel sermaye ve insan unsurunun sürekli gelişimi için alternatif bir yaklaşım: Insana yatırım standardı (IIP). Journal of Yasar University, 10(40), 6645-6659.

Özdemirci, F., \& Aydın, C. (2008). Kurumsal bilgi kaynakları ve bilgi yönetimi. Türk Kütüphaneciliği, 22(1), 59-81.

Seyidoğlu, H. (1999). Ekonomik terimler ansiklopedik sözlük (2. Baskı). İstanbul: Gizem Can Yayınları.

Shareef, F., \& Davey, H. (2005). Accounting for intellectual capital: Evidence from listed English football clubs. Journal of Applied Accounting Research, 7(3), 78-116.

Starovic, D., \& Marr, B. (2004). Understanding corporate value: Managing and reporting intellectual capital. The Chartered Institute of Management Accountants (CIMA) and Cranfield University, London. Avaible at: http://www.cimaglobal.com/Documents/ImportedDocuments/intellectualcapital.pdf

Sönmezoğlu, U., \& Çoknaz, D. (2014). Yönetici bakış açısıyla spor kulüplerinde kurumsallaşma: Spor Toto Süper Lig örneği. E-Journal of New World Sciences Academy, 9(1), 1-21.

Ünlü, O. (2015). Stratejik bilgi yönetimi enstrümanlarından entelektüel sermayenin boyutları arasındaki ilişkisinin incelenmesi: Türk prefabrik sektörü üzerine bir araştırma. Süleyman Şah Üniversitesi Sosyal Bilimler Enstitüsü, Yayınlanmamış Doktora Tezi, İstanbul. 
Vatansever, Y. (2009). İşletmedeki bilgi altyapısının entelektüel sermayenin gelişimine etkisi ve bir uygulama. Gebze Yüksek Teknoloji Enstitüsü Sosyal Bilimler Enstitüsü, Yayınlanmamış Doktora Tezi, Gebze.

Yılmaz, B., \& Halıcı, A. (2010). İşgücü devir hızını etkileyen: sekreterlik mesleğinde bir araştırma. Uluslararası iktisadi ve idari incelemeler Dergisi, 2(4), 93-108.

Yorulmaz, M., \& Alkan, G. (2018). Deniz ulaştırma işletmelerinde entelektüel sermaye ve örgüt performansı arasındaki ilişkide yenilikçiliğin rolü. Business and Economics Research Journal, 9(3), 631-650.

\section{İnternet Kaynakları}

https://b-fit.com.tr/tr (Erişim tarihi, Ekim 2017).

https://www.turkcebilgi.com/entelektüel (Erişim tarihi, 25 Ekim 2017).

https://www.turkcebilgi.com/sermaye\#bilgi (Erişim tarihi, 25 Ekim 2017). 